\title{
KESESUAIAN KONDISI OSEANOGRAFI DALAM MENDUKUNG EKOSISTEM TERUMBU KARANG DI PERAIRAN PULAU PARI
}

\section{COMPATIBILITY OF OCEANOGRAPHIC CONDITIONS IN SUPPORTING CORAL REEFS ECOSYSTEM IN PARI ISLAND COASTAL WATER}

\author{
Corry Corvianawatie ${ }^{1,2} \&$ Muhammad Abrar ${ }^{2}$ \\ ${ }^{1}$ Pusat Penelitian Oseanografi, Lembaga Ilmu Pengetahuan Indonesia \\ Jalan Pasir Putih I Ancol Timur, Jakarta Utara 14430, Indonesia \\ ${ }^{2}$ Loka Pengembangan Kompetensi SDM Oseanografi, Lembaga Ilmu Pengetahuan Indonesia \\ Jalan Raden Saleh No.43 Cikini, Jakarta Pusat 10330, Indonesia \\ e-mail : corr002@lipi.go.id / corvianawatie@gmail.com \\ Diterima tanggal: 09 Desember 2017 ; diterima setelah perbaikan: 28 September 2018 ; Disetujui tanggal: 05 Desember 2018 \\ DOI: http://dx.doi.org/10.15578/jkn.v13i3.6322
}

\begin{abstract}
ABSTRAK
Parameter kualitas air laut meliputi suhu, salinitas, $\mathrm{pH}$, dissolved oxygen (DO), dan kekeruhan (turbiditas) memiliki peran yang penting bagi biota laut. Karang merupakan salah satu biota yang sangat sensitif terhadap perubahan kualitas air laut, khusunya Suhu Permukaan Laut (SPL). Kondisi kualitas air yang melebihi ambang batas yang dapat ditolerir oleh karang, diduga dapat menghambat laju pertumbuhan maupun proses resiliensinya. Penelitian ini bertujuan untuk memahami kondisi oseanografi dan kesesuaiannya dalam mendukung ekosistem terumbu karang di Perairan Pulau Pari. Pengukuran kualitas air secara in-situ dilakukan pada Maret dan Juni 2015 di PR01 (Daerah Perlindungan Biota Laut), PR02 (Goba Pulau Tikus), dan PR03 (Bintang Rama) yang merupakan area ekosistem terumbu karang. Selain itu dilakukan pula pengukuran di 14 stasiun pengamatan untuk mengetahui pola kualitas air secara spasial. Hasil penelitian menunjukkan, nilai sebaran SPL berkisar antara 28,5 - 29,5 ${ }^{\circ} \mathrm{C}$; salinitas berkisar 29,0 - 30,5 psu; pH berkisar 8,3 - 8,43 satuan; turbiditas berkisar 0 - 1,4 NTU; dan DO berkisar antara $4-5,3 \mathrm{mg} / \mathrm{L}$. Kondisi tersebut menunjukkan kualitas air masih sesuai dengan baku mutu air laut khususnya bagi karang, sesuai yang ditetapkan oleh Menteri Lingkungan Hidup Republik Indonesia, kecuali untuk parameter salinitas dan DO (Juni 2015) yang berada di bawah ambang batas minimum.
\end{abstract}

Kata kunci: Oseanografi, terumbu karang, Pulau Pari, baku mutu air laut.

\begin{abstract}
Seawater quality include temperature, salinity, $\mathrm{pH}$, Dissolved Oxygen (DO), and turbidity variability have significant impact on marine organism. Coral is one of marine biota that is sensitive to the changes of sea water quality, mainly sea surface temperature. Seawater conditions that exceed the threshold, suggested can inhibit corals growth rate as well as its resilience process. This research is aiming to understanding oceanographic condition and its compatibility in supporting coral reef ecosystem in Pari Island. Sea water quality was measured on March and June 2015 at PR01 (Marine Protected Area of Pari Island), PR02 (Tikus Island), and PR03 (Bintang Rama). The measurement were also conducted at 14 station around Pari Island to understand its spatial pattern. This study results shows the range of sea surface temperature are $28.5-29.5^{\circ} \mathrm{C}$; salinity of sea water is in the range of 29.0-30.5 PSU; pH in the range 8.3-8:43 units; turbidity is in the range 0-1.4 NTU; and DO is in the range of $4-5.3 \mathrm{mg} / \mathrm{L}$. The sea water quality in those two months are suitable for coral life according to the standard which is determined by the Minister of Environment of the Republic of Indonesia, except for salinity and DO value (in June 2015) which is below the minimum threshold.
\end{abstract}

Keywords: Oceanography, coral reef, Pari Island, seawater quality standard. 


\section{PENDAHULUAN}

Pulau Pari yang merupakan salah satu tujuan wisata laut di DKI Jakarta, berada di Kepulauan Seribu atau $\sim 50 \mathrm{~km}$ sebelah utara Teluk Jakarta. Terumbu karang merupakan salah satu objek yang menjadi daya tarik wisata di Pulau Pari. Berdasarkan peta ekoregion laut Indonesia, Perairan Pulau Pari termasuk dalam ekoregion laut 6 yang secara umum kondisi lingkungan maupun ekosistemnya mengalami degradasi cukup signifikan akibat pencemaran (Kementerian Lingkungan Hidup, 2013). Dinamika perairan di wilayah ini dipengaruhi oleh pasang surut yang bertipe campuran cenderung diurnal di Laut Jawa (Kementerian Lingkungan Hidup, 2013; Pranowo et al., 2014; Widisantosa et al., 2016), sistem angin monsun (Kementerian Lingkungan Hidup, 2013; Pranowo et al., 2014), dan fenomena iklim global seperti Indian Ocean Dipole (IOD) dan El Nino Southern Oscillation (ENSO) (Fadlan et al., 2017; Heryati et al., 2018). Kondisi fisis oseanografi yang dinamis dapat menyebabkan perubahan pada kualitas air laut.

Karang merupakan salah satu biota laut yang sensitif terhadap perubahan kualitas air laut. Diduga perubahan kualitas air laut merupakan salah satu faktor yang dapat mengganggu pertumbuhan maupun proses resiliensi karang (Obura \& Grimsditch, 2009). Adapun parameter-parameter kualitas air tersebut meliputi suhu, salinitas, $\mathrm{pH}$, DO, kekeruhan, arus laut, gelombang, dan pasang surut. Beberapa studi yang telah dilakukan menyatakan bahwa kenaikan suhu permukaan laut sebesar $1-2^{\circ} \mathrm{C}$ di atas nilai rata-ratanya dan bertahan dalam periode waktu tertentu dapat menghambat pertumbuhan karang (Cantin et al., 2010; Cooper et al., 2008; Purnamasari, 2009; Cahyarini, 2011) dan menyebabkan pemutihan karang (HoeghGuldberg, 1999; Wouthuyzen et al., 2015; 2018). Faktor lainnya seperti penurunan salinitas air laut akibat adanya run-off dari sungai diduga juga dapat menghambat pertumbuhan karang (Grove et al., 2010), menyebabkan peningkatan nutrien dan sedimen yang kemudian memicu terjadinya penyakit karang, ledakan populasi alga, dan keruhnya air laut sehingga menghambat penetrasi cahaya matahari dalam air laut (Greet Barrier Reef Marine Park Authority, 2017; Roberts \& Harriott, 2003). Proses pengasaman air laut atau penurunan $\mathrm{pH}$ air laut juga merupakan salah satu ancaman bagi karang karena dampaknya yaitu mereduksi kemampuan karang untuk membentuk rangkanya (Cooper et al., 2008; Greet Barrier Reef Marine Park Authority, 2017).
Terdapat beberapa lokasi snorkeling atau diving yang selalu dimonitor kondisi terumbu karangnya yaitu PR01 (Daerah Perlindungan Biota Laut Pulau Pari), PR02 (Goba Pulau Tikus), dan PR03 (Bintang Rama). Lokasi dan karakteristik dari ketiga stasiun ini berbedabeda yaitu PR01 berada di tubir bagian selatan Pulau Pari dan PR03 berada di tubir bagian utara gugus Pulau Pari, sedangkan PR02 berada di dalam Goba Pulau Tikus yang areanya lebih terlindung oleh gelombang dan arus laut daripada dua lokasi lainnya. Berdasarkan perbedaan karakteristik tersebut maka diperlukan kajian mengenai kualitas air laut di masing-masing stasiun dan penilaian kemampuannya dalam mendukung pertumbuhan serta resilensi karang.

Sebelumnya, studi mengenai kondisi kualitas air laut dalam mendukung proses resiliensi karang di Pulau Pari telah dilakukan pada 2013 dan 2014. Hasil dari penelitian tersebut menyimpulkan bahwa kualitas perairan berada pada kondisi normal dan mendukung pertumbuhan serta perkembangan karang, akan tetapi masih belum optimal untuk mendukung proses resiliensi (Abrar et al., 2014). Berdasarkan informasi tersebut maka studi ini bertujuan untuk memahami variabilitas kualitas air laut pada Maret dan Juni 2015 yang mewakili kondisi musim peralihan dan musim timur dalam mendukung ekosistem terumbu karang.

\section{BAHAN DAN METODE}

Dalam studi ini dilakukan pengambilan data kualitas air laut secara sesaat di tiga stasiun pengukuran yaitu PR01, PR02, dan PR03 pada Maret dan Juni 2015, serta dilakukan pengukuran sesaat di 14 titik pengukuran mengelilingi Perairan Gugus Pulau Pari pada Maret 2015 (Tabel 1 dan Gambar 1). Dalam penelitian ini diasumsikan pengukuran pada Maret dapat mewakili kondisi perairan pada musim peralihan, sedangkan pengukuran pada Juni mewakili kondisi perairan pada musim timur.

Parameter kualitas air laut yang diukur meliputi suhu, salinitas, $\mathrm{pH}$, turbiditas, dan DO. Kelima parameter tersebut diukur menggunakan Water Quality Checker (WQC-24) TOA DKK yang sudah dikalibrasi sesuai dengan prosedur yang tepat sebelum digunakan. Pengukuran di tiga stasiun utama dilakukan sebanyak lebih dari lima kali pengulangan, sedangkan pengukuran spasial di 14 titik hanya dilakukan tiga kali pengulangan. Data kualitas air pada Maret dan Juni 2015 dibandingkan menggunakan grafik. Selain data kualitas air, dilakukan pula pengukuran kecepatan arus sesaat menggunakan flowmeter di lokasi stasiun 


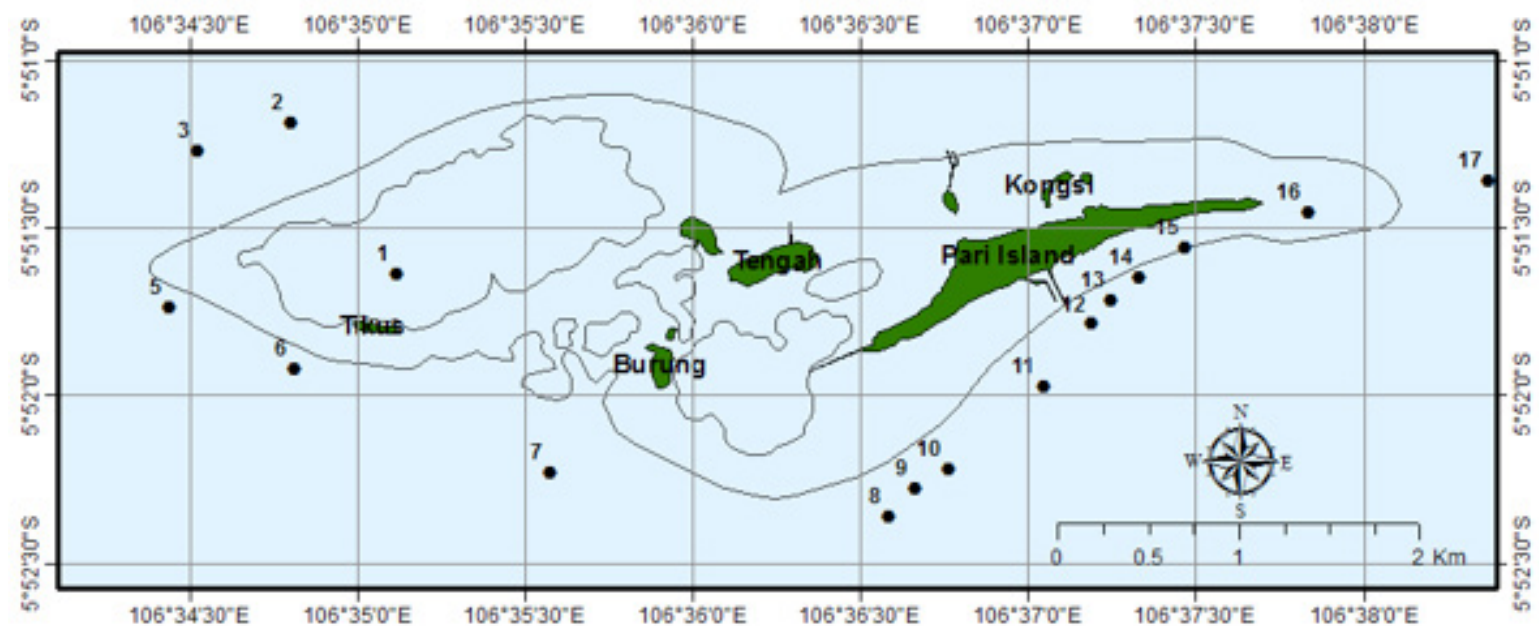

Gambar 1. Peta stasiun pengukuran kualitas air di Pulau Pari.

Figure 1. Monitoring station map of seawater quality at Pari Island coastal waters..

Tabel 1. Koordinat stasiun dan waktu pengamatan

Table 1. Station coordinat and observation time

\begin{tabular}{|c|c|c|c|}
\hline Station & Latitude ( $\left.{ }^{\circ} \mathrm{S}\right)$ & Longitude $\left({ }^{\circ} \mathbf{E}\right)$ & Time \\
\hline 1 (PR02) & 5,8605 & 106,5852 & 15 Mar 2015 10:20 \\
\hline 1 (PR02) & 5,8605 & 106,5852 & 17 Jun 2015 15:15 \\
\hline 2 (PR03) & 5,8530 & 106,5799 & 14 Mar 2015 15:36 \\
\hline 2 (PR03) & 5,8530 & 106,5799 & 17 Jun 2015 13:34 \\
\hline 3 & 5,8545 & 106,5753 & 14 Mar 2015 16:50 \\
\hline 4 & 5,8572 & 106,5648 & 14 Mar 2015 17:00 \\
\hline 6 & 5,8653 & 106,5802 & 14 Mar 2015 17:10 \\
\hline 7 & 5,8705 & 106,5928 & 14 Mar 2015 17:20 \\
\hline 8 & 5,8727 & 106,6097 & 14 Mar 2015 17:30 \\
\hline 9 & 5,8712 & 106,6110 & 15 Mar 2015 12:22 \\
\hline 10 (PR01) & 5,8703 & 106,6126 & 15 Mar 2015 13:46 \\
\hline 10 (PR01) & 5,8703 & 106,6126 & 17 Jun 2015 12:00 \\
\hline 11 & 5,8661 & 106,6173 & 15 Mar 2015 15:08 \\
\hline 12 & 5,8630 & 106,6198 & 14 Mar 2015 17:40 \\
\hline 13 & 5,8619 & 106,6207 & 15 Mar 2015 15:14 \\
\hline 14 & 5,8607 & 106,6222 & 15 Mar 2015 15:16 \\
\hline 15 & 5,8593 & 106,6244 & 15 Mar 2015 15:21 \\
\hline 16 & 5,8575 & 106,6305 & 15 Mar 2015 15:25 \\
\hline 17 & 5,8560 & 106,6395 & 15 Mar 2015 15:33 \\
\hline
\end{tabular}

pengamatan.

\section{HASIL DAN PEMBAHASAN}

Hasil pengukuran di ketiga stasiun pengamatan menunjukkan nilai SPL pada bulan Maret lebih rendah daripada Juni 2015 (Gambar 2). Perbedaan SPL antara kedua bulan tersebut mencapai $1{ }^{\circ} \mathrm{C}$. Rentang nilai SPL pada Bulan Maret dan Juni 2015 yaitu yaitu $28,50-29,30{ }^{\circ} \mathrm{C}$. SPL lebih tinggi pada Bulan Maret dibandingkan dengan Bulan Juni yang diduga disebabkan oleh penyinaran matahari yang lebih intensif dan minimnya tutupan awan. Meskipun begitu, peningkatan suhu permukaan air laut di Pulau Pari masih sesuai dengan ambang batas baku mutu air laut untuk biota karang yang ditetapkan oleh Menteri Lingkungan Hidup RI yaitu berada dalam rentang 28 $30^{\circ} \mathrm{C}$. Hasil pengukuran juga menunjukkan kesesuaian dengan hasil model SPL di area ini yang berada pada rentang $28,75-29,5{ }^{\circ} \mathrm{C}$ (Pranowo et al., 2014)

Kondisi SPL pada Bulan Juni 2015 relatif homogen di ketiga stasiun pengamatan. Berbeda halnya dengan hasil pengukuran pada Bulan Maret 2015 yang menunjukkan adanya perbedaan SPL antara PR01, 
PR02, dan PR03 pada Maret 2015. SPL di PR03 lebih tinggi daripada kedua stasiun lainnya. Hal ini karena perbedaan waktu pengukuran yaitu suhu permukaan laut di PR03 diukur pada pukul 15:36, sedangkan SPL di PR01 diukur pada pukul 13:46 dan SPL di PR02 diukur pada pukul 10:20. Hal ini dapat dijelaskan oleh adanya pemanasan matahari yang semakin intensif pada pukul 14:00 - 15:00 sehingga suhu permukaan laut di PR03 terukur paling tinggi dibandingkan lokasi lainnya. Selain itu kondisi ini didukung pula oleh lokasi PR03 yang terbuka, berbeda dengan PR02 yang semi tertutup.

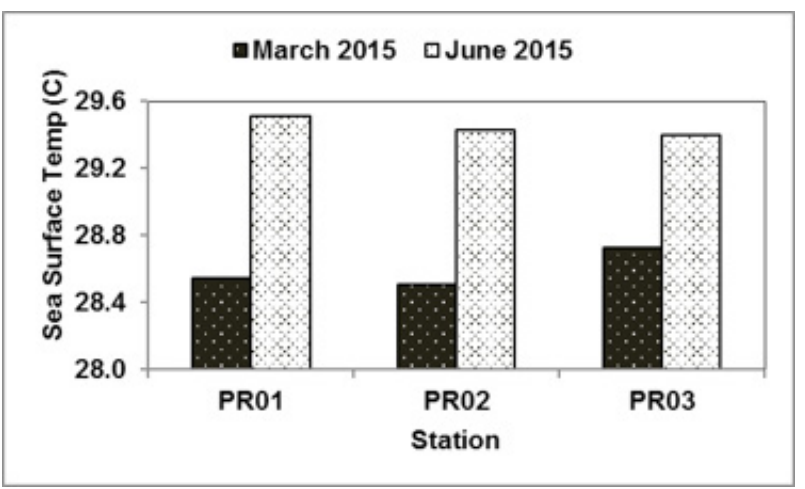

Gambar 2. Hasil pengukuran suhu permukaan laut di PR01, PR02, dan PR03.

Figure 2. Measurement result of sea surface temperature at PR01, PR02, and PRO3.

SPL di wilayah Pulau Pari Kepulauan Seribu memiliki pola yang hampir sama dengan suhu permukaan laut di Pulau Jawa. Suhu permukaan laut cenderung lebih tinggi pada musim peralihan dibandingkan dengan suhu permukaan laut pada musim timur maupun musim barat. Hal ini dikarenakan lemahnya kekuatan angin permukaan laut pada musim peralihan. Hasil penelitian di Pulau Pari pada tahun Agustus 2011 menunjukkan suhu permukaan laut relatif lebih tinggi pada awal Bulan Agustus (musim peralihan menuju musim timur) dibandingkan dengan suhu permukaan laut pada pertengahan Bulan Agustus yang sudah memasuki puncak musim timur (Widisantosa et al., 2016). Hal ini menjelaskan pula suhu pemukaan laut yang lebih rendah pada Bulan Maret yang disebabkan oleh kuatnya angin monsun barat yang berhembus di Perairan Pulau Pari.

Secara umum, salinitas air laut mengalami peningkatan pada Juni 2015 (Gambar 3), kecuali di PR01. Terjadinya peningkatan salinitas disebabkan oleh tingginya penguapan dan minimnya curah hujan (presipitasi) pada musim peralihan menuju musim timur. Rentang nilai salinitas di area ini yaitu 29,20
- 30,50 PSU, sedangkan ambang batas baku mutu air laut untuk karang yaitu 33-34 PSU dengan variasi $<5 \%$ dari salinitas rata-rata musiman. Apabila anomali salinitas air laut masih dalam rentang 5\% dari rata-rata musimannya, maka dapat disimpulkan bahwa kondisi salinitas masih sesuai bagi pertumbuhan karang. Jika dibandingkan dengan nilai standar baku mutu yang telah ditetapkan oleh Kementrian Lingkungan Hidup RI, nilai in-situ salinitas ini jauh di bawah ambang batas. Hasil pengukuran ini juga menunjukkan nilai salinitas lebih rendah dibandingkan hasil model salinitas untuk area ini yaitu 30,25 - 31,75 PSU (Pranowo et al., 2014).

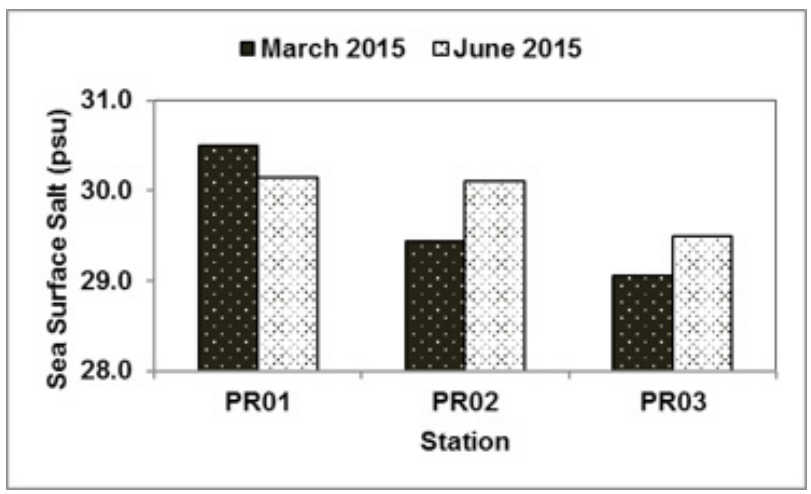

Gambar 3. Hasil pengukuran salinitas permukaan laut di PR01, PR02, dan PR03.

Figure 3. Measurement result of sea surface salinity at PR01, PR02, and PR03.

Dari ketiga stasiun pengamatan tersebut, terdapat perbedaan salinitas yang cukup signifikan pada pengukuran Maret 2015. Salinitas di PR03 tercatat paling rendah. Hal ini diduga disebabkan pengaruh hujan pada 14 Maret 2015 yang menyebabkan rendahnya salinitas. Sebaliknya pada 15 Maret 2015 tidak terjadi hujan sebagaimana hari sebelumnya. Kondisi ini menyebabkan terjadinya pemanasan matahari dan penguapan air laut yang intensif. Akibatnya salinitas air laut di PR01 terukur lebih tinggi dibandingkan salinitas di PR02 yang diukur pada pukul 13:46 di mana pemanasan matahari paling intensif.

Selain suhu dan salinitas, kekeruhan air laut merupakan salah satu parameter yang penting untuk dianalisis karena perannya yang signifikan terhadap ekosistem terumbu karang. Secara keseluruhan kondisi kekeruhan di tiga stasiun pengukuran masih berada di bawah ambang batas maksimum yaitu 5 NTU (Gambar 4). Rentang kekeruhan air laut di Pulau Pari berada pada nilai 0 - 1,50 NTU. Kekeruhan air laut rata-rata lebih tinggi pada Bulan Maret dibandingkan dengan Bulan Juni. Hal ini diduga disebabkan oleh perbedaan fase pasang surut pada saat pengukuran. Kekeruhan air laut 


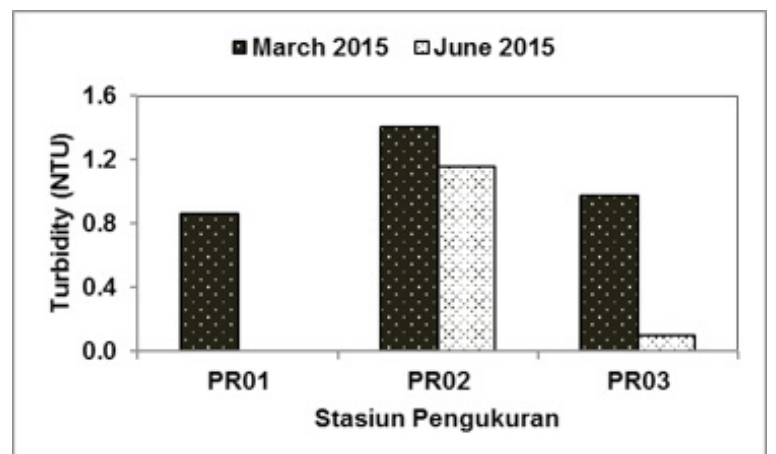

Gambar 4. Hasil pengukuran turbiditas air laut di PR01, PR02, dan PR03.

Figure 4. Measurement results of turbidity at PR01, PR02, and PRO3.

cenderung lebih tinggi pada kondisi pasang menuju surut karena partikel-partikel sedimen ikut terbawa ke lepas pantai oleh arus.

Dari ketiga stasiun pengukuran diketahui pula turbiditas di PR02 paling tinggi dibandingkan lainnya. Hal ini dikarenakan profil dasar laut dari PR02 merupakan pasir halus, sedangkan profil dasar dari PR01 dan PR03 merupakan pasir kasar. Kondisi dasar perairan yang didominasi oleh pasir halus lebih mudah teraduk oleh gerakan massa air di permukaan.

Kondisi turbiditas air laut masih sesuai dengan baku mutu air laut baik pada Bulan Maret dan Juni 2015. Akan tetapi DO air laut menunjukkan kondisi yang berbeda. DO air laut pada Maret masih sesuai dengan baku mutu air laut yaitu $>5,0 \mathrm{mg} / \mathrm{L}$, sedangkan pada bulan Juni terjadi penurunan DO mencapai $4 \mathrm{mg} / \mathrm{L}$ yang menunjukkan bahwa kondisi DO tidak memenuhi baku mutu air laut (Gambar 5). Diduga karena pada Juni kecepatan angin permukaan lebih lemah daripada Maret sehingga pengadukan massa air di permukaan

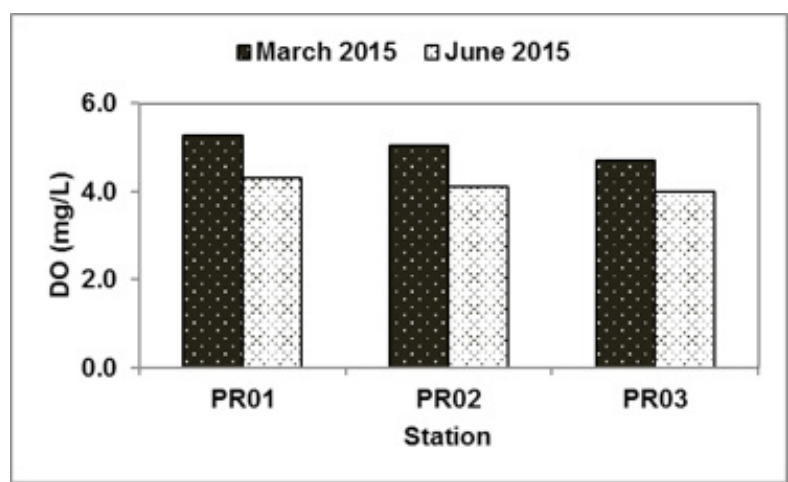

Gambar 5. Hasil pengukuran DO air laut di PR01, PR02, dan PR03.

Figure 5. Measurement results of DO at PR01, PR02, and PRO3. melemah dan menyebabkan DO air laut lebih rendah. Adapun kondisi ini sesuai dengan hasil penelitian sebelumnya yang menyatakan bahwa rentang nilai DO di area ini berkisar antara 4,1 hingga $4,3 \mathrm{mg} / \mathrm{L}$ (Pranowo et al., 2014).

Variabilitas kualitas air laut juga terlihat pada parameter $\mathrm{pH}$. Terjadi peningkatan $\mathrm{pH}$ sebesar 0,02 hingga 0,03 pada Juni 2015 di stasiun PR01 dan PR02 (Gambar 6). Hal ini dimungkinkan karena adanya perubahan suhu, Dissolve Inorganic Carbon (DIC), dan alkalinitas. $\mathrm{pH}$ perairan berada pada rentang 8,3 hingga 8,4 satuan. Hal ini menunjukkan bahwa nilai $\mathrm{pH}$ perairan di seluruh stasiun pengamatan masih sesuai dengan ambang batas baku mutu air laut yaitu berada di rentang 7,0 $-8,5$ satuan.

Secara umum kondisi kualitas air laut di Perairan Gugus Pulau Pari masih sesuai dengan baku mutu air laut yang telah ditetapkan oleh Menteri Lingkungan Hidup. Akan tetapi parameter yang diukur tersebut tidak sepenuhnya dapat dianggap mewakili kondisi pada masing-masing bulan Maret dan Juni 2015 Hal ini dikarenakan metode pengukuran yang hanya dilakukan sesaat, padahal perubahan kualitas air laut sangat dinamis dipengaruhi oleh banyak faktor Contohnya yaitu suhu permukaan laut dan salinitas air laut yang memiliki variabilitas baik secara harian maupun musiman. Begitu pula parameter DO dan turbiditas yang sangat dipengaruhi oleh pasang surut dan variabilitas angin permukaan.

Arus laut di ketiga stasiun pengamatan pada Maret 2015 memiliki kisaran nilai $0,1-0,15 \mathrm{~m} /$ detik dengan arah arus bervariasi dari tenggara hingga selatan Kondisi ini sesuai dengan hasil penelitian terdahulu di area ini menyatakan bahwa arus laut pada monsun

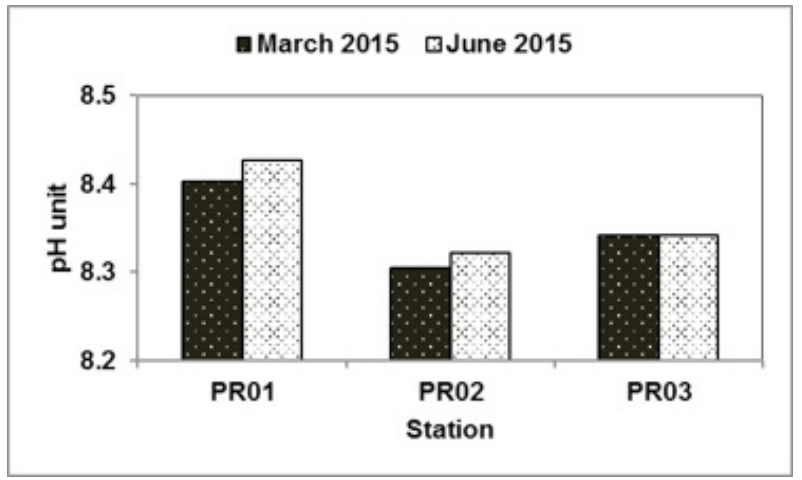

Gambar 6. Hasil pengukuran pH air laut di PR01, PR02, dan PR03.

Figure 6. Measurement results of $\mathrm{pH}$ at PR01, PR02, and PRO3. 
barat berada pada kisaran $0,15-0,3 \mathrm{~m} /$ detik ke arah tenggara (Pranowo et al., 2014). Kondisi yang hampir sama terlihat pada Juni 2015 arus laut memiliki kisaran nilai $0,1-0,3 \mathrm{~m} /$ detik dengan arah tenggara hingga selatan. pada monsun peralihan I berada pada kisaran 0,08 - 0,2 $\mathrm{m} /$ detik ke arah utara dan barat laut (Pranowo et al., 2014). Adapun perbedaan arah arus laut hasil pengukuran dan referensi diduga disebabkan oleh dominasi arus pasang surut pada saat pengukuran. Sebagaimana diketahui pola arus di wilayah pesisir dominan dipengaruhi oleh fenomena pasang surut.

Hasil penelitian ini menunjukkan bahwa secara umum kondisi kualitas air laut di Pulau Pari masih sesuai dengan baku mutu kualitas air laut, akan tetapi tetap diperlukan analisis lebih lanjut untuk mengetahui apakah kondisi tersebut sudah mendukung proses resiliensi karang. Berdasarkan Obura \& Grimsditch (2009) dalam bukunya tentang protokol penilaian resiliensi terumbu karang, terdapat beberapa kriteria penilaian untuk menyatakan apakah suatu parameter dapat mendukung proses resiliensi. Untuk itu diperlukan data time series yang lebih panjang untuk hasil yang lebih akurat sebagai dasar untuk mengambil kesimpulan.

\section{KESIMPULAN DAN SARAN}

Secara umum kondisi suhu, salinitas, DO, turbiditas, dan $\mathrm{pH}$ perairan Pulau Pari masih sesuai dengan ambang batas baku mutu air laut untuk kehidupan karang yang ditetapkan oleh Menteri Lingkungan Hidup, kecuali untuk parameter salinitas dan DO pada pengukuran Juni 2015. Hasil penelitian juga menunjukkan adanya kesesuaian pola kualitas air laut sebagaimana hasil penelitian sebelumnya (Pranowo et al., 2014; Widisantosa et al., 2016). Kondisi oseanografi di Pulau Pari memiliki variabilitas secara spasial dan temporal yang dipengaruhi oleh angin monsun dan fenomena pasang surut. Pengaruh pasang surut air laut terlihat jelas pada pola arus laut di Pesisir Perairan Pulau Pari. Adanya dominasi fenomena pasang surut dibandingkan angin monsun menyebabkan arah arus laut mengikuti pola gelombang pasang surut.

Hasil studi ini mewakili kondisi oseanografi Pulau Pari pada Bulan Maret dan Juni. Namun begitu, untuk analisis yang lebih komprehensif disarankan dilakukan pengukuran secara berkala. Hal ini dapat bermanfaat untuk menganalisis kesesuaian kondisi perairan dalam mendukung proses pertumbuhan maupun resiliensi karang. Seperti halnya pada parameter salinitas air luat, diketahui bahwa nilai salinitas berada jauh di bawah rentang baku mutu. Namun belum dapat dipastikan bahwa kondisi salinitas air laut tersebut tidak sesuai untuk pertumbuhan karang. Perlu dilakukan pengukuran secara kontinu parameter salinitas air laut dan parameter oseanografi lainnya, sehingga dapat diketahui rata-rata musimannya. Melalui informasi tersebut selanjutnya dapat dianalisis bagaimana

Tabel 2. Pengukuran in-situ kualitas air laut di Pulau Pari pada Maret 2015

Table 2. In-situ observation of water quality at Pari Island in March 2015

\begin{tabular}{|c|c|c|c|c|}
\hline \multirow[t]{2}{*}{ Parameters } & \multicolumn{3}{|c|}{ Station } & \multirow[t]{2}{*}{ Baku Mutu (Standards) } \\
\hline & PR01 & PR02 & PR03 & \\
\hline Suhu & 28,60 & 28,50 & 28,70 & $28-30^{\circ} \mathrm{C}$ \\
\hline Salinitas & 30,50 & 29,50 & 29,20 & 33 - 34 PSU \\
\hline $\mathrm{pH}$ & 8,40 & 8,30 & 8,34 & $7-8,5$ satuan \\
\hline DO & 5,40 & 5,20 & 5,00 & $>5 \mathrm{mg} / \mathrm{L}$ \\
\hline Kekeruhan & 0,80 & 1,40 & 1,00 & $<5 \mathrm{NTU}$ \\
\hline
\end{tabular}

Tabel 3. Pengukuran in-situ kualitas air laut di Pulau Pari pada June 2015 Table 3. . In-situ observation of water quality at Pari Island in June 2015

\begin{tabular}{|c|c|c|c|c|}
\hline \multirow[t]{2}{*}{ Parameters } & \multicolumn{3}{|c|}{ Station } & \multirow[t]{2}{*}{ Baku Mutu (Standards) } \\
\hline & PR01 & PR02 & PR03 & \\
\hline Suhu & 29,50 & 29,40 & 29,30 & $28-30^{\circ} \mathrm{C}$ \\
\hline Salinitas & 30,00 & 29,92 & 29,50 & 33 - 34 PSU \\
\hline $\mathrm{pH}$ & 8,42 & 8,31 & 8,34 & $7-8,5$ satuan \\
\hline DO & 4,20 & 4,10 & 4,00 & $>5 \mathrm{mg} / \mathrm{L}$ \\
\hline Kekeruhan & 0,00 & 1,10 & 0,10 & $<5 \mathrm{NTU}$ \\
\hline
\end{tabular}

JURNAL KELAUTAN NASIONAL, Vol. 13, No 3, Desember 2018, Hal. 155-161 
korelasi antara anomali parameter oseanografi dan pertumbuhan dan proses resiliensi karang.

\section{UCAPAN TERIMA KASIH}

Ucapan terima kasih kami sampaikan kepada seluruh tim peneliti dan teknisi yang membantu dalam proses pengambilan data oseanografi. Kami mengucapkan terima kasih pula kepada reviewer Jurnal Kelautan Nasional atas masukan yang diberikan untuk artikel ini.

\section{DAFTAR PUSTAKA}

Abrar, M., Herandarudewi, S. M. C., Siringoringo, R. \& Wibowo, K. (2014). Resiliensi dan Perlindungan Habitat Terumbu di Perairan Gugus Pulau Pari, Kepulauan Seribu, Jakarta, Laporan Kegiatan Penelitian, UPT Loka Pengembangan Kompetensi SDM Oseanografi Pulau Pari, Lembaga Ilmu Pengetahuan Indonesia.

Cahyarini, S. Y. (2011). Pertambahan Penduduk, Variasi Interannual Suhu Permukaan Laut dan Pengaruhnya terhadap Pertumbuhan Linier Karang Porites di Kepulauan Seribu, Jurnal Lingkungan dan Bencana Geologi, 2 (1): 39-48.

Cantin, N. E., Cohen, A. L., Karnauskas, K. B., Tarrant, A. M. \& McCorkle, D. C. (2010). Ocean Warming Slows Coral Growth in the Central Red Sea, Science, 329: 322-325.

Cooper, T. F., De'ath, G., Fabricius, K. E. \& Lough, J. M. (2008). Declining coral calcification in massive Porites in two nearshore regions of the northern Great Barrier Reef. Global Change Biology, 14: 529538.

Fadlan, A., Sugianto, D. N., Kunarso. \& Zainuri, M. (2017). Influence of ENSO and IOD to Variability of Sea Surface Height in the North and South of Java Island. IOP Conf. Series: Earth and Environmental Science, 55 (012021): 1 - 10.

Greet Barrier Reef Marine Park Authority. (2017). Climate Change Impact on Corals. Diakses 1 Desember 2017 dari http://www.gbrmpa.gov.au/managing-the-reef/ threats-to-the-reef/climate-change/what-does-thismean-for-species/corals

Grove, C. A., Nagtegaal, R., Zinke, J., Scheufen, T., Koster, B., Kasper, S., McCulloch, M. T., van den Bergh, G. \& Brummer, G. J. A. (2010). River runoff reconstruction from novel spectral luminescence scanning of massive coral skeleton. Coral Reefs, 29: 579-591.

Heryati, H., Pranowo, W. S., Purba, N. P., Rizal, A. \& Yuliadi, L. P. S. (2018). Java Sea Surface Temperature Variability during ENSO 1997-1998 and 2014-2015. Omni Akuatika, 14(1): 96-107.

Hoeh-Guldberg, O. (1999). Climate change, coral bleaching and the future of the world's coral reefs. Mar.
Freshwater Res., 50: 839-866.

Kementerian Lingkungan Hidup. (2013). Deskripsi Peta Ekoregion Laut Indonesia. Kementerian Linkungan Hidup, Deputi Tata Lingkungan. Jakarta. Indonesia, $1-230$.

Obura, D. O. \& Grimsditch, G. (2009). Resilience Assessment of coral reefs - Assessmemt protocol for coral reefs, focusing on coral bleaching and thermal stress. IUCN working group on Climate Change and Coral Reefs, IUCN, Gland, Switzeland, 1-70.

Pranowo, W. S., Pramono, G., Hutomo, M., Nontji, A. \& Maufikoh, I. (2014). Karakteristik Oseanografi Ekoregion Laut Provinsi DKIJakarta. Dinamika Teluk Jakarta: Analisis Prediksi Dampak Pembangunan Tanggul Laut Jakarta (Jakarta Giant Sea Wall). IPB Press. Bogor. Indonesia, 43 - 56.

Purnamasari, I. A. (2009). Analisis Pertumbuhan Linier Koral dan Korelasinya dengan Perubahan Lingkungan (Studi Kasus Koral Kepulauan Seribu). Tugas Akhir: Program Studi Oseanografi, Institut Teknologi Bandung.

Roberts, L. G. \& V. J. Harriott. (2003). Can environmental records be extracted from coral skeletons from Moreton Bay, Australia, a subtropical, turbid environment. Coral Reefs, 22: 517-522.

Widisantosa, H., Pranowo, W. S., Simanjuntak, S. M. \& Setiadi, H. (2016). Studi Konstanta Harmonik Pasang Surut terhadap Data Suhu Permukaan Laut di Perairan Pulau Pari. Jurnal Chart Datum, 2 (2): 32 - 43.

Wouthuyzen, S., Abrar, M. \& J. Lowrens (2015). Coral Bleaching Incidents of 2010 in Indonesian Waters Revealed Through Analysis of Sea Surface Temperature. Oseanologi dan Limnologi di Indonesia, 1: 305-207.

Wouthuyzen, S., Abrar, M. \& Lowrens, J. (2018). A comparison between the 2010 and 2016 El-Nino induced coral bleaching in the Indonesian waters. IOP Conference Series: Earth and Environmental Science, 118. 
